\title{
Hajóbaleset a Dunán 1868-ban
}

\author{
Boat accident on the Danube in 1868
}

\begin{abstract}
Absztrakt
A magyarországi folyami gőzhajózás első balesete 1868-ban történt a Dunán. A lényegesen nagyobb Karl Ludwig hajó két megye határán beleütközött a S1avonia gőzösbe, amelynek következtében két utas meghalt. A korabeli hazai jogból hiányoztak azok az alapvető büntetőjogi normák, amelyek alapján a felelősségről dönteni kellett. Az eljárásban felelősségre vont hajóskapitányokat az 1873-ban jogerössé vált döntéssel felmentette a bíróság.
\end{abstract}

Kulcsszavak: Duna, gőzhajózás, hajóütközés, hajózási szabályok, büntetőjogi felelösség, gondatlan emberölés, per, ítélet, felmentés

\begin{abstract}
The first accident of river steamboats in Hungary occurred in 1868 on the Danube. The significantly larger Karl Ludwig crashed into the steamship Slavonia on the border of two counties, resulting in the death of two passengers. In national criminal law the rules and regulations necessary for determining criminal liability in such a case did not exist at that time. In its final decision of 1873 , the court acquitted the prosecuted ship captains.
\end{abstract}

Keywords: Danube, steamboat, boat crash, shipping rules, criminal liability, careless murder, litigation, judgment, acquittal

A dunai hajózás hosszú történetében olykor előfordultak olyan események, amelyek lefolyásukat, eredményüket tekintve kiemelkedtek a hétköznapokból. Ilyen volt az az 1868 őszén történt baleset is, amelynek következtében az összeütközött személyszállító hajók kapitányai büntetőbíróság elé kerültek. Az ügy büntetőjogunk történetében vélhetően az első eset volt, amikor a közlekedés e fajtájának körében történt eredmény bekövetkezése miatt kellett a felelősségről dönteni. Ráadásul olyan körülmények között, amikor a polgári magyar állam kiépítése 
éppen csak megkezdődött, az erre hivatott szervek müködésük kezdetét élték, s az országban hiányzott a kodifikált anyagi és eljárási büntetőjog. Az ügy ismertetését nehezíti, hogy a keletkezett hivatalos iratanyag - ami alapján a történet hitelesen megállapítható lenne - már nincs meg. Viszont az akkoriban megjelent, a történteket hủen ismertető, az eljárt szervek munkájáról beszámoló sajtó egymást is kiegészítő tudósításai révén rekonstruálható az eset és annak elbírálása.

A modernizálódó Magyarországon már az 1830-as években megindult az akkori legfejlettebb müszaki megoldást jelentő gőzhajókkal a dunai személy- és teherfuvarozás. A kor legjelentősebb folyami hajóstársasága a bécsi székhelyü Első Dunagőzhajózási Társaság (Erste Donau-Dampfschiffahrts Gesellschaft - DDSG) volt, amely számos hajójáratot üzemeltetett a birodalom területén. Üzleti erejét és szállítási kapacitását jellemezte, hogy a dualizmus kezdetén Magyarországot illetően 90 gőzhajója 8000 lóerő teljesítménnyel, míg a teherszállításra 297 vontával rendelkezett. A Kiegyezés évében, 1867-ben alakult pesti Első Magyar Gőzhajózási Társaság 12 gőzöse 870 lóerővel bírt. E cég 1868 augusztusától a főváros és a Dráva-menti Eszék között naponta közlekedtetett járatokat. A fél 6-kor induló hajó menetrend szerint 17 órakor futott be a kb. 250 km-re fekvő Apatinba, ahol az utasok a Slavonia gőzösre átszállva 21 órára érkeztek Eszékre. Másnap, kora reggel indult vissza a hajó, amiről apatini átszállással 8-kor mehettek tovább az utasok Pestre. (A Magyar Mérnök Egyesület Közlönye 1870/3. 211-212. és Pesti Napló 1868/187.).

Ebben a rendszerben azonban 1868. október 10-én, szombaton este 20 óra körül rendkívüli esemény következett be: a Duna jobb oldalán völgymenetben haladó Slavonia gőzösbe Bezdán és Apatin között, Vörösmart és Monostorszeg magasságában beleütközött a DDSG Orsováról felhajózó Karl Ludwig nevü személyszállító gőzöse. A folyam kanyarulatából kibukkant, változatlan sebességgel a jobb part irányába haladó majd háromszoros nagyságú hajó orra betörte a kisebb gőzös bal oldalát, annak vaslemezén több méternyi rést ütve, így a hajótestbe zúdult a víz. Az ütközés erejétől megbillent Slavonia fedélzetén tartózkodó utasokból többen a folyamba zuhantak. Az összeütközést követően a Karl Ludwig folytatta útját. A Slavonia-t 1868 augusztus végétől parancsnokló Návay Kálmán kapitány - észlelve, hogy a Duna közelebbi, baranyai partján annak meredeksége miatt nem tud kikötni - a túlsó, Bács-bodrogi part felé kormányoztatta a még múködő gépü megrongált hajót. A bal irányba fordított sérült gőzösnek - a hajógép utolsó leheletével - sikerült kb. 380 méternyi ívet megtéve a túlpartot szinte elérnie, ahol az addigra vízzel telt Slavonia félig süllyedt a Dunába. Az utasok itt már nem voltak veszélyben, majd az odaérkezett DDSG Johann vontatógőzös fedélzetén elhagyták a helyszínt. Az ütközést követő zürzavarban nem lehetett pontosan megállapítani az esetleges 
áldozatok számát, a Slavonia utasai közül többeket - a híradások 6-14 fö között ingadoztak - nem találtak a süllyedés után. A balesetben a Karl Ludwig orra is megsérült valamelyest.

A történtekről a sajtó részletesen és folyamatosan tudósított, az eset rendkívüliségét egy híradás akként értékelte, hogy az „Aldunán történt szerencsétlenség oly nagy volt, milyen ott nem igen történt még”. (Fővárosi Lapok 1868/240. 963.).

A baleset miatt azonnal megindult a vizsgálat, amelyet nem az esemény helyszíne szerinti valamelyik vármegye szerve folytatott, hanem a Magyar Királyi Közmunka- és Közlekedési Minisztérium 1868. szeptember 1-jétől megalakult Vasúti és Hajózási Főfelügyelősége. Az ennek hatáskörét meghatározó utasítás szerint ugyanis ez volt jogosult a „vasúti és vízi közlekedés biztonságára, rendességére és szabályszerüségére vonatkozó törvények, rendeletek és utasitások szigorú megtartása fölött örködni és arról gondoskodni, hogy az észrevett nehézségek és akadályok mielöbbi eltávolitása mellett a törvény- és szabályellenességek megszüntettessenek és a vétkesek törvényes feleletre vonattassanak". (Budapesti Közlöny 1868/271.2555.).

Az ügyben e szerv hajózási osztályának vezetője, a korszak legnagyobb hazai tengeri és folyamhajózási ismeretekkel és tapasztalatokkal rendelkező szakembere - a magyar szaknyelvet is alapvetően megteremtő - Kenessey Albert vezette a vizsgálatot. Ennek során a bírói feladatokat Pest szabad királyi város fenyítő törvényszéke látta el, a mellette működő tiszti ügyészség közremüködésével. Az akkoriban még teljesen szabályozatlan eljárás során megtörtént a részben vízben álló Slavonia szemléje éppúgy, mint az óbudai hajógyárban javított Karl Ludwig-é, valamint a hajók utasainak, személyzeteinek, kapitányainak kihallgatása. Novemberben kiemelték a mederből a megsérült gőzhajót, és a testén tátongó rést ideiglenesen megszüntetve egy újpesti dokkba szállították.

A magyarországi folyamhajózásra ekkoriban - hazai joganyag hiányában - a Kiegyezés előtt kiadott ausztriai birodalmi normákban megfogalmazott szabályozók voltak az irányadók. Ezek az 1815-ös bécsi kongresszusi okmány azon elöírásain nyugodtak, miszerint a rendészeti szabályok minden folyóra nézve egységesen, az érintett államok által egyoldalúan meg nem változtatható módon kerülhetnek megállapításra. Erre figyelemmel a császári-királyi kereskedelmi miniszternek az 1850-es években hozott rendeletei határozták meg a hajózás legfontosabb szabályait, a személyi, müszaki követelményeket. Ezek közül alapvető volt azon elöírás, amely szerint a „Dunán hajózó minden gözösnek egy saját vezetönek felelös vezérlete alatt kell állania, ki az erre nézve megkivántató ismereteket s gyakorlati képességet magának megszerezte s minden szükséges tulajdonságok iránt magát igazolni köteles". (Magyarországot illető Országos Kormánylap 1858/V. 143.). 
Az önálló hazai szabályozást már a baleset után gróf Mikó Imre közmunka és közlekedési miniszter 1869. április 21-i, az addigi normákra figyelemmel megalkotott rendelete jelentette, amely bevezetöjében megállapította, hogy „Magyarországban a folyó-, csatorna-s tóhajózásra vonatkozó törvények és rendszabályok nem léteznek". Az ennek mellékleteként közölt Ideiglenes folyó-, csatorna- és tói hajózási rendszabályok részletesen szóltak mindazon elöírásokról, amelyek kötelezőek voltak a szabályos és biztonságos vízi közlekedés érdekében. Ennek 4. §-a is leszögezte az alaptételt, miszerint a ,vezetö személyesen felelös, hogy a vezetése alatt álló hajó [...] jó karban tartassék, a szükséges személyzet, a hajó nagyságának és czéljának megfelelö tartozékok meg legyenek, a hajó rendesen terhelve s jól vezetve legyen; általában mindazért, mit ezen minőségben müvel vagy mulaszt”. (Magyarországi Rendeletek Tára 1869 564-618.). Részletesen szabályozást nyertek a hajózás körüli általános elővigyázat és a különös előírások kérdései, mint például a jármủvek haladása, kivilágítása, egymás közti érintkezése, segítése.

A baleset miatti vizsgálat során nagyszámú személy kihallgatása történt meg, akik - attól függően, hogy melyik hajón voltak a balesetkor - eltérően emlékeztek a történtekre, körülményekre. Annyi megállapítható volt, hogy a Duna kanyarulatából előbukkant, hegymenetben szabályos menetirányát elhagyó Karl Ludwig-ot a Slavonia kapitánya és a fedélzetén tartózkodó utasok észlelték. Návay Kálmán az ütközést kerülendő lassíttatta hajója sebességét és figyelmeztető fütyüléseket adatott le a gőzgéppel, megverette a harangot, az utasok pedig kiáltoztak a közeledő nagyobb hajó felé. Közben a kapitány felhívatta a szalonban tartózkodókat a fedélzetre. A figyelmeztetésekre nem reagáló Karl Ludwig változatlanul folytatva haladását, nekiütközött a kisebb jármünek. A nagyobb gőzösön tartózkodók elmondása szerint viszont a Slavonia nem volt kivilágítva, azt nem lehetett észlelni. Hadda László, a Karl Ludwig kapitánya szerint hiányoztak a hajóról a szabályosan égő lámpák, így legfeljebb uszálynak vélte a közeledő hajó sötét tömegét, a Slavonia fedélzetéről pedig csak az ütközés után hangzottak el a figyelmeztető jelzések. A nagy zajban a két kapitánynak nem sikerült magát megértetnie, így a Slavonia egy ívet húzva a balpart felé tartott, míg a Karl Ludwig tovább hajózott felfelé a Dunán.

A tudósítások szerint a vizsgálat arra a következtetésre jutott, hogy a Karl Ludwig parancsnoki hídján az ütközést megelőzően nem volt jelen sem Hadda, sem König Sándor másodkapitány, míg a „keréknél álló egyetlen kormányos nem hagyhatta ott helyét, hogy az illetöket a lent mulató inspector köréböl felhívja". (Magyarország és a Nagyvilág 1868/44. 554.).

A vizsgálat 1868 őszi befejezését követően huzamosabb ideig semmiféle hír nem látott napvilágot a balesetről. Több mint három és fél év elteltével - ami 
alatt megszervezést nyert az állami igazságszolgáltatás - viszont közlést nyert, hogy három föt, az összeütközött hajók kapitányait a Pesti Királyi Ügyészség megvádolta azon tényállás alapján, miszerint az ,,1868. évben egy napon este 8 órakor a Slavonia gőzhajó lefelé úszván, a szakálasi foknál Monostor közelében a Karl Ludwig gözhajóval összeütközött, mely alkalommal a Slavonia oly annyira összezúzatott, hogy majd elsüllyedt, ha a Johann gözhajó nem sietett volna segitségére”. (A Hon, 1872/180.). Az ütközés következménye emberhalál és tetemes anyagi károkozás lett.

Az ügyet 1872. augusztus 5-6-án tárgyalta a Pesti Királyi Törvényszék három fős bírói tanácsa egy szokatlan és akkoriban alkalmazni kezdett jogforrás alapján. Az Igazságügyi Minisztérium államtitkára, Csemegi Károly 1872 február végére készítette el a teljes kodifikálatlanság oldására $A$ törvényszékek illetöségéhez tartozó bünvádi eljárás ideiglenes szabályozásáról szóló törvény javaslatát, amely röviden szólt az elsőfokú eljárás szabályairól. Ezt a Képviselőház igazságügyi bizottsága némileg átszövegezte, de megtárgyalására az Országygyülés feloszlása miatt nem került sor. Ebben a helyzetben Bittó István igazságügy-miniszter a törvényszékek elnökeit az 1872. május 1-jei körlevelében arra hívta fel, hogy iparkodjanak a bíráknál ,,odahatni, miszerint az ebben foglalt intézkedések ... a fennforgó bünvádi ügyek körül alkalmaztassanak”. (Képviselőház irományai 1869/XV. 119-154., Baróthy 1897 35.).

A per első napján történt kihallgatásokkor Návay, a Slavonia kapitánya állította, hogy a „Carl Ludvig minden harangozása és fütyölése daczára meg nem állt, hanem hajójával összeüttözzött úgy, hogy ha az ott átmenö János nevü teherhajó nem fogadja be a kiszállni kénytelen utasokat, sok ember vesztette volna életét". Ezzel szemben Adda és König első- és másodkapitányok szerint a kisebb hajón „csak egy lámpa égett, úgy, hogy csak uszályhordónak nézték. Később a felfelé menö Carl Ludvig megállt, a Szlavónia azonban a part másik oldalára fordult és ezen alkalommal a megállott Carl Ludviggal ütközött össze. Ezen két eltérö véleményre szakadnak a tanúkép kikérdezve lett utasok, és azok akik akkor a két hajón, valamint a János nevü szállitóhajón szolgáltak. Tisztázódott, hogy az ütközés következtében egy diakóvári tanitó két gyermeke lelte halálát, mivel az egyik a Szlavóniába beható vízben fulladt meg, a másiknak tüdögyulladása a meghülés folytán annyira nött, hogy Apatinba vitetvén, azonnal meghalt", a hajóban pedig 31.888 forint kár keletkezett. (Budapesti Közlöny 1872/180. 1440.). A második napon hangzottak el a vád- és védőbeszédek. Ezek során Csukássy Károly alügyész a , két gyermek halálából kiindulva, Návay és Adda kapitányokat vétkes mulasztás által okozott emberölés miatt 6-6 havi fogságra itélni" indítványozta, míg Funták Sándor védöügyvéd a „védenczeit felmentetni kéri, miután a bekövetkezett szerencsétlenségnek kiszámíthatatlan és a vádlottaknak 
fel nem róható okai vannak”. A törvényszék ezeket követően „több mint félórányi tanácskozás után Addát és Königet, a Carl Ludvig első és második kapitányait az élet biztonsága elleni vétség miatt 14 napi fogságra, valamint az okozott és polgári perúton megállapitandó kár megfizetésére itélte”, míg Návay Kálmánt felmentette. (Budapesti Közlöny 1872/180. 1440.).

Az ítélet meghozatala azonban nem ment könnyen: mint a korabeli jól értesült szaklap, a Jogtudományi Közlöny később tudatta a ,, hármas bíróság egyik tagja nem vélte a tényálladékot megállapithatónak, míg a másik két biró, tehát a többség a tényálladékot helyreállitva vélte; a bünösség kérdésére kerülvén a szavazás, az egyik bíró tényálladék hiánya, silletöleg meg nem állapíthatása folytán a két hajóskapitány egyikét sem mondhatá bünösnek, a másik két bíró közül pedig az egyik Pétert, a másik Pált találta bünösnek! Ekkép nem juthatván többségre, a tárgyalást vezető bíró úr szavazásra hívatott még két törvényszéki bírót, kik közül egyik sem volt jelen a tárgyalásnál és szavaztak birótársaik rövid elöterjesztései alapján! Hogy ezen eljárás bírálatra nem szorul, azt mindenki belátja”. (Dárdai, 1873, 126.).

A bíróság döntése meghozatalakor ismeretlen helyzetben volt, hiszen ilyen üggyel a magyar joggyakorlat korábban nem találkozott. Büntetö törvénykönyv nem lévén, az addigi szokásjogra és a kibontakozó jogirodalomra támaszkodhatott döntése meghozatalakor. Ekkoriban a hazai büntető igazságszolgáltatás számára viszonyítási pontként a pesti egyetem tanárának, Pauler Tivadarnak a Büntetőjogtan című könyve szolgált. Ez kódexszerúen összegezte a büntetőjogi ismereteket: a mủ az egyes szakaszoknál bemutatta az alapvetően szokásokon alapult hagyományos hazai jog, az 1843-as büntetőjogi javaslat és az 1852-es - Magyarországon 1861-ig hatályos - ausztriai birodalmi Btk. megoldásait, kiegészítve a külföldi jogirodalommal és a szerző magyarázataival. A könyv 420. §-a szerint - figyelemmel az 1852-es Btk. 335, 336, 337. §-aira-életbiztonság elleni vétségnek minősült, ha a sértett halálát nem szándékos, de mégis vétkes magatartás okozta, amely ,elbízottság vagy vigyázatlanságból [...] veszi eredetét”. A szerző ismét e Btk-ra utalva írta, ha a „vigyázatlanság különösen veszélyes tárgyak körül vagy körülmények közt követtetett el", akkor meghatározott tartamú szabadságvesztést kell alkalmazni, míg a szokás szerint Magyarországon a büntetés a bíró belátásától függött. (Pauler, 1870 154-156.).

A törvényszék ítéletének kihirdetése után hosszabb procedúra vette kezdetét, amelynek tartalma az egyes bírósági szintek döntéseinek indokait illetően nem ismert, de végeredménye a Magyarország és a Nagyvilág címü folyóirat 1873. július 13-án megjelent számában közzétett kúriai határozatból megismerhető. Az 1872. augusztus 6-i ítélet ellen a királyi ügyészség, valamint a két elítélt kapitány fellebbezett. Ezeket elbírálva a Pesti Királyi Ítélötábla 1872. november 
4-i végzésével megsemmisítette az elsőfokú határozatot és a törvényszéket új ítélet hozatalára utasította. Az erre hozott és az eredeti ítéletet fenntartó 1873. február 14-i határozat elleni fellebbezések elbírálásaként az ítélőtábla 1873. március 3-án újra megsemmisítette a törvényszék döntését és a korábbi táblai végzés pontos teljesítésére, vagyis új ítélet hozatalára és annak szabályszerü kihirdetésére utasította az elsőfokú bíróságot. Erre a Pesti Királyi Törvényszék 1873. március 14-én hozta meg újabb, az eredetit megismétlő ítéletét. Ezt a királyi tábla már érdemben elbírálva 1873. április 7-én döntött a fellebbezésekröl. Ebben kiindulási pontként leszögezte, ahhoz, hogy „,minden jogi kételyt kizárólag kimondathassák az életbiztonság elleni vétség a vádlott hajóskapitányok melyike által követtetett el”, feltétlenül szükséges „1. megállapitása azon iránynak, melyen a két összeütközö gözös haladott; 2. megjelölése a helynek, hol az összeütközés történt; 3. bebizonyitása annak, elmulasztatott-e és melyik részröl a kellö elövigyázat". (Magyarország és a Nagyvilág 1873/28. 360.).

A tábla megállapította, hogy ezen alaptételeket a törvényszék rögzítette, mint az „elsö birósági itélet által is jelzett vezéreszmét”, azonban a terjedelmes vizsgálat és a végtárgyalás eredményeként csak azt lehetett kimondani, hogy a , $k i$ hallgatott számos tanúk majdnem mindegyike azon gőzhajó kapitánya mellett tanúskodnak, melynek hajóján voltak, s a bekövetkezett emberhalált eredményezö szerencsétlenség elöidézőjének, az ellenök jövő másik hajós kapitányt jelölik ki”. Ennélfogva a „tömegesen eltérö ellentétes tanúvallomások egyikének a másika fölött előnyt adni annál kevésbé lehet, mert a hajók irányáról, s arról, minő erővel haladott a gőzös, kellő szakismeret hiányában bizonyítékot nem nyújthatnak, föleg ha figyelembe vétetik az, hogy sokan olyan körülményröl is tanúskodnak, mely a vizsgálat fejleménye által teljesen megczáfolva van". (Magyarország és a Nagyvilág 1873/28. 360.).

A per során bebizonyosodott, hogy az ütközést megelőzően mindhárom kapitány hajója vezérlőhídján volt, továbbá a Karl Ludwig kevéssel az ütközés elött a Ferdinand Max és Johann nevü gőzösöket ,kellö úton haladva kikerülte". Tény az is, hogy a Slavonia lámpái a „hajózási rendszabályok ellenére, habár hivatalos tudomás szerint eltörve, nem az árboczon vagy kéményen, hanem alant a rúdon voltak illesztve”. Így Addának azon előadása, miszerint ő a „hajót világitásánál fogva tutajnak nézte, az intézkedéseket eleve ehhez képest tette meg, vétkességet annál kevésbé sem képezhet, mert a tutajnak vélt gözhajót fölismerve, a hajószemélyzet és a vele utazó kapitányok egyező tanúsítása szerint hajóját meglassította, illetőleg megállítását elrendelte". Az ítélőtábla szerint a Slavonia kapitánya és legénysége által említett azon körülmény, hogy a másik hajó a veszélyt jelző figyelmeztetésükre nem ügyelt, ,teljesen elenyészik azáltal, hogy a Carl Ludvig személyzete, úgy az utasok állitása szerint a jelzés csak 
közvetlen a veszély percze elött hallván, az összeütközést meggátolható nem volt”. (Magyarország és a Nagyvilág 1873/28. 360.).

Mindezek alapján és mivel a szakértői nyilatkozat szerint az, hogy a „hajók minö irányban haladtak, hol történt az összeütközés, meg nem állapitható; miután végül az, hogy a hajózási szabályok vádlottak mindegyike vagy melyike által szegetett meg, ellenükbe be nem bizonyittathatik, jelesen Návay K. ellenében az, hogy a hajó lámpái szabályellenes helyen voltak illesztve, miután arra készüléke nem volt, bünül föl nem róható, a szabályok esetében pedig ezeken kívül még más tényleges viszonyok tekintetbe nem vétele által vétkes vigyázatlanság követtetett volna el, semmivel sincs igazolva”, ezért a Karl Ludwig kapitányait a vád alól ,,alanyi tényálladék meg nem állapíthatása miatt” felmentette, míg az ítéletnek Návay Kálmánra vonatkozó részét fenntartotta. (Magyarország és a Nagyvilág 1873/28. 360.).

A felülvizsgálat eredményeként a Kúria, mint legfőbb ítélőszék 1873. június 10-i határozatával az ítélőtáblai ítéletet indokainál fogva helyben hagyta. Így zárult a hazai jogtörténet első gépi meghajtású hajók közötti ütközési ügye, amelynek hatásaként is megszületett a hazai hajózást évtizedekig meghatározó szabályozás. Az ügy főszereplői közül a helyreállított Slavonia az 1872. augusztus 20-i fővárosi regattán már részt vett. Az Első Magyar Gőzhajózási Társaság megszüntével és hajóinak a DDSG-hez kerülésével pedig Návay Kálmán is e cégnél nyert alkalmazást a továbbiakban. 


\section{Felhasznált irodalom}

Az Aldunán történt szerencsétlenség. Fővárosi Lapok 1868/241. 963.

Ideiglenes utasitás az 1868. évi september 1-én életbeléptetett magy. kir. vasúti és hajózási föfelügyelöség hatáskörét illetöleg. Budapesti Közlöny 1868/271. 2555.

A kereskedelmi ministeriumnak 1858. január 29-kén kelt rendelete, kiható minden koronaországokra, a katonai határőrséget kivéve, a Dunáni hajózásra és tutajozásra megkivántató ausztriai igazolványok elnyerése tárgyában. Magyarországot illető Országos Kormánylap 1858/V. 143. A magy. kir. közlekedésügyi minister körrendelete az ország összes törvényhatóságaihoz. Magyarországi Rendeletek Tára Pest 1869 564-618.

A vasúti és hajózási magy. kir. föfelügyelöség hatásköréhez tartozó közlekedési vállalatok 1869dik évi forgalmára vonatkozó statistikai adatok. A Magyar Mérnök Egyesület Közlönye 1870/3. 211-212.

A magyar gözös hajótörése oct. 10-én. Magyarország és a Nagyvilág 1868/44. 554.

A Karl Ludwig és Slavonia gőzhajók összeütközése. A Hon 1872/180.

Az elsöf. pesti királyi törvényszék. Budapesti Közlöny 1872/180. 1440.

A Carl Ludvig és Slavonia gőzhajók összeütközése. Magyarország és a Nagyvilág 1873/28. 360.

Baróthy M. (1897): A budapesti királyi föügyészség által 1872. január hó 1-töl 1897. év május hó l-ig kibocsátott körrendeletek időszerinti gyüjteménye. Budapest: Hunnia Kiadó

Dárdai S. (1873): A közvetlenség elve a bünvádi eljárásban. Jogtudományi Közlöny, 16, 126.

Pauler T. (1870): Büntetőjogtan II. - Anyagi büntetöjog különös része, alaki jog. Pest: Pfeifer Ferdinánd

Törvényjavaslat, a törvényszékek illetöségéhez tartozó bünvádi eljárás ideiglenes szabályozásáról. Az 1869-dik évi april hó 20-dikára hirdetett Országgyűlés Képviselőházának irományai XV. kötet Pest 1872 119-154.

\section{A cikkben szereplő online hivatkozások}

URL1: Elsö Magyar Gözhajózási Társaság. http://www.hajoregiszter.hu/tarsasagok/belvizi/ elso_magyar_gozhajozasi_tarsasag/194 